\title{
Video Pembelajaran Berbasis Multimedia Interaktif dalam Meningkatkan Keterampilan Menyimak Anak Usia Dini
}

\author{
Eka Juannita $^{1}$, Nenny Mahyuddin ${ }^{1}$ \\ Pendidikan Anak Usia Dini, Universitas Negeri Padang, Indonesia(1) \\ DOI: $\underline{10.31004 / o b s e s i . v 6 i 4.2198}$
}

\begin{abstract}
Abstrak
Segala aktivitas anak berkaitan dengan keterampilan menyimak. Anak memahami bahasa berdasarkan konsep pengetahuan dan pengalaman. Hal ini penting jika anak memiliki kemampuan menyimak yang baik, anak akan lebih memahami apa yang dijelaskan oleh guru ataupun orang dewasa. Rendahnya keterampilan menyimak bisa jadi disebabkan oleh kurangnya media pembelajaran yang mendukung anak dalam proses belajar. Tujuan penelitian yaitu menghasilkan video pembelajaran berbasis multimedia interaktif untuk meningkatkan keterampilan menyimak anak. Jenis penelitian ialah R\&D dengan model ADDIE. Teknik analisis data yaitu kualitatif dan kuantitatif. Hasil penelitian video pembelajaran berbasis multimedia interaktif untuk meningkatkan keterampilan menyimak anak dengan hasil penilaian yang dilakukan ahli materi, ahli media, ahli bahasa dan anak usia 5-6 tahun dengan kualifikasi sangat baik. Selain itu multimedia interaktif dapat membuat belajar anak menjadi lebih variatif sehingga pembelajaran lebih menarik, memotivasi anak serta dapat memberikan pengalaman belajar bagi anak.
\end{abstract}

Kata Kunci: video pembelajaran; multimedia interaktif, keterampilan menyimak.

\begin{abstract}
All children's activities are related to listening skills. Children understand language based on the concept of knowledge and experience. This is important if the child has good listening skills, the child will better understand what is explained by the teacher or adult. Low listening skills could be caused by the lack of learning media that supports children in the learning process. The research objective is to produce interactive multimedia-based learning videos to improve children's listening skills. The type of research is R\&D with the ADDIE model. Data analysis techniques are qualitative and quantitative. The results of the research on interactive multimedia-based learning videos to improve children's listening skills were assessed by material experts, media experts, linguists and children aged 5-6 years with very good qualifications. In addition, interactive multimedia can make children's learning more varied so that learning is more interesting, motivates children and can provide learning experiences for children.
\end{abstract}

Keywords: learning video; interactive multimedia; listening skills.

Copyright (c) 2022 Eka Juannita, Nenny Mahyuddin.

$\triangle$ Corresponding author :

Email Address : ekajuannita21@gmail.com (Padang, Indonesia)

Received 29 November 2021, Accepted 17 January 2022, Published 15 February 2022 


\section{PENDAHULUAN}

Anak usia dini adalah sosok individu yang sedang menjalani suatu proses perkembangan yang pesat dan fundamental bagi kehidupan selanjutnya. Menurut Sujiono (2013) anak usia dini adalah manusia kecil yang memiliki potensi yang harus dikembangkan dengan karakteristik yang khas dan tidak sama dengan orang dewasa, mereka selalu aktif, dinamis, antusias terhadap apa yang dilihat dan didengar, dirasakan, tidak pernah berhenti berekplorasi dan belajar. Anak usia 5-6 tahun sudah memiliki kemampuan dalam berbahasa, seperti sudah dapat mengucapkan lebih dari 2.500 kosakata, mampu menjadi pendengar yang baik, dan dapat berpartisipasi dalam satu percakapan dengan orang lain (Puspitasari, 2019). Hal ini menunjukan bahwa anak usia dini merupakan individu yang unik dengan memiliki beberapa tahapan perkembangan yang harus dicapai dan distimulasi dengan pendidikan sejak dini.

Pengembangan bahasa pada anak mengarahkan anak agar mampu menggunakan dan mengekspresikan pemikirannya dengan menggunakan kata-kata (Widyastuti, 2018). Bahasa sangat berperan penting dalam kehidupan anak karena bahasa merupakan alat komunikasi dalam kehidupan sehari-hari, dengan bahasa anak dapat menyampaikan ide, pikiran, perasaan kepada orang lain baik secara lisan maupun tulisan. Terdapat empat aspek keterampilan berbahasa salah satunya ialah keterampilan menyimak. Menurut (Mianawati, R, Hayati, T, \& Kurnia, 2019) keterampilan menyimak merupakan keterampilan bahasa yang termasuk dalam bahasa reseptif, artinya keterampilan yang harus dikuasai oleh anak sebagai dasar keterampilan berbahasa yang lain.

Hal senada juga dikemukakan (Tarigan, 2015) menyimak adalah proses mendengarkan lambang-lambang lisan dengan penuh perhatian, pemahaman apresiasi, serta interpretasi untuk memperoleh informasi, menangkap isi atau pesan serta memahami makna komunikasi yang disampaikan oleh pembicara melalui ujaran. Aspek pertama yang dimiliki oleh anak yaitu keterampilan menyimak. Hal ini sebagaimana pemaparan dalam penelitian (Oduolowu, E \& Oluwakemi, A, 2014) menyimak merupakan keterampilan bahasa pertama yang dikembangkan anak dan merupakan keterampilan komunikasi yang paling dominan dalam kehidupan sehari-hari, hal ini dilihat dari studi yang dilakukan pada aspek mendengar diperkirakan sekitar 50\% digunakan untuk menyimak/mendengar.

Menyimak adalah bagian penting dalam membangun hubungan yang baik dengan orang lain, yang berguna untuk melakukan keterlibatan langsung secara individu maupun kelompok. Anak dikategorikan aktif dalam menyimak apablia mampu merespons dan menaruh perhatian pada ujaran yang mereka dengar (Ariawan, V, A, N., Agustin, E, D., 2019). Tingkat pencapaian perkembangan anak usia 5-6 tahun dalam aspek menerima bahasa (reseptif) ialah anak yang mampu menyimak perkataan orang lain, mengerti beberapa perintah secara bersamaan, menjawab pertanyaan sesuai pernyataan (Sulaiman, U., Ardianti, N., 2019).

Menyimak merupakan keterampilan berbahasa yang paling mendasar yang harus dimiliki oleh anak, karena apabila sudah memiliki keterampilan menyimak yang baik maka anak akan mudah untuk membicarakan apa yang didengarnya, mampu memahami apa yang dibacanya dan mampu menulis dengan baik apa yang didengarnya dari hasil simakan.Keterampilan menyimak meskipun tidak menunjukkan keluaran yang tampak akan tetapi menjadi salah satu faktor keberhasilan anak dalam perkembangannya. Studi terdahulu menunjukkan bahwa keterampilan menyimak anak berkaitan erat satu sama lain dengan keterampilan berbahasa khususnya berbicara. Anak yang berkembang keterampilan menyimaknya akan berpengaruh terhadap perkembangan keterampilan berbicaranya. Segala aktivitas anak berkaitan dengan keterampilan menyimak, anak belajar berbicara melalui simakan begitu juga respons yang ditujukan anak berdasarkan hasil simakan (Dewi., Suwatra., \& Magta, 2016). 
Tingkat keterampilan menyimak yang termasuk dalam aspek perkembangan bahasa anak usia dini yang diperkuat oleh Standar Tingkat Pencapaian Perkembangan Anak (STTPA) yang terdapat di dalam Permendikbud No. 146 tahun 2014, menyebutkan anak usia 5-6 tahun, adalah anak yang sudah mampu menceritakan kembali apa yang didengar dengan kosa kata yang lebih, dan melaksanakan perintah yang lebih kompleks sesuai dengan aturan yang disampaikan (Kemendikbud, 2014).

Berdasarkan observasi yang dilakukan peneliti terhadap perkembangan bahasa dalam aspek keterampilan menyimak anak usia 5-6 tahun di TK Miftahul Ilmi masih ditemukan rendahnya keterampilan menyimak menyebabkan anak kurang memahami ujaran yang didengarkan, ditambah kurangnya bantuan media pembelajaran yang mendukung anak dalam proses pembelajaran yang berdampak pada munculnya gejala frustasi pada diri anak. Gejala frustasi yang muncul pada anak menjadikan ia sulit berkonsentrasi, dan termotivasi sehingga tidak dapat memperhatikan pembelajaran dengan baik. Selain itu anak belum mampu menginterpretasikan suatu cerita atau informasi yang didengarnya berdasarkan kemampuan bahasa dan daya imajinasinya.

Rendahnya tingkat kemampuan menyimak anak pada dasarnya disebabkan oleh dua hal yaitu faktor dari dalam diri anak itu sendiri, seperti minat dan motivasi anak dalam belajar kurang, anak masih sulit untuk mendengarkan dengan penuh perhatian terlihat anak mudah bosan pada saat belajar mengajar berlangsung, tidak memperdulikan perintah yang disampaikan oleh guru. Sementara itu faktor dari luar diri anak ialah pembelajaran untuk keterampilan menyimak anak belum optimal karena berbagai hal diantaranya guru masih belum menerapkan pengembangan cara mengajar yang inovatif untuk anak, guru kurang mengikuti perkembangan teknologi dalam mengembangkan suatu media pembelajaran yang menarik minat anak, dan media pembelajaran berupa video pembelajaran berbasis multimedia interaktif belum ada di Taman Kanak-kanak Miftahul Ilmi.

Dengan adanya permasalahan tersebut sangat dibutuhkan dalam mengarahkan anak pada proses kegiatan pembelajaran yang lebih bermakna yakni dapat dilakukan melalui media (Retnaningrum, 2016). Media pembelajaran yang baik yaitu media yang memberi kesempatan pada anak untuk mendapatkan juga memperkaya pengetahuan secara langsung (Nurhafizah, 2018). Untuk itu perlunya peran guru dalam mengembangkan media pembelajaran yang bervariasi dan menarik bagi anak. Penggunaan media pembelajaran sangat penting, karena media pembelajaran berpengaruh besar dalam memotivasi keinginan anak untuk belajar dan media pembelajaran juga membantu guru memberikan informasi serta dapat membantu proses pembelajaran anak (Sukiman, 2012). Salah satu media yang menarik perhatian anak adalah video pembelajaran berbasis multimedia interaktif.

Video pembelajaran sebagai media yang berperan sebagai pengantar informasi dari guru kepada anak. Menurut Limbong, Tonni \& Simarmata (2020) berpendapat kata video berasal dari singkatan bahasa inggris yaitu visual dan audio. Kata Vi adalah singkatan dari visual yang berarti gambar, kata Deo adalah singkatan dari audio yang berarti suara. Dengan adanya audio visual anak dapat melihat tindakan nyata dari apa yang tertuang dalam media tersebut, hal ini mampu merangsang motivasi belajar anak (Putu, Sudarma, \& Yuda, 2019). Selanjutnya (Pradilasari, 2019) berpendapat kelebihan dari menggunakan audio visual dalam pembelajaran yakni pesan atau materi yang disampaikan mudah untuk dipahami, dipahami dan disimpan dalam ingatan sehingga akan berpengaruh nyata terhadap hasil belajar ranah kognitif, afektif, dan psikomotorik anak, selain itu dapat mengatasi keterbatasan jarak dan waktu, serta dapat diulang untuk meningkatkan pemahaman.

Dalam penggunaannya video merupakan kumpulan beberapa komponen yang berfungsi sebagai pengiriman suara serta gambar bergerak (Asmoro, 2019). Penggunaan media video pembelajaran dapat merangsang motivasi anak untuk belajar. Hal ini juga dikemukakan (Rismark, Marit \& Selvberg, 2019) studi menunjukkan bahwa video juga dapat berfungsi dengan baik sebagai sarana untuk mendorong pembelajar. Karena ada rasa ingin 
tahu anak mengenai video yang ditampilkan sehingga dapat meningkatkan pemahaman anak terhadap materi yang diberikan (Kirana, 2016).

Video pembelajaran juga dikemas secara menarik menggunakan tampilan dari multimedia interaktif yang telah dirancang agar tampilannya dapat memenuhi fungsinya yaitu dengan menginformasikan suatu pesan yang dilengkapi dengan alat pengontrol yang dapat dioperasikan oleh penggunannya (anak). Video pembelajaran berbasis multimedia interaktif merupakan media yang bisa melibatkan pengalaman anak secara langsung dengan melibatkan semua indera. Seperti yang dikatakan Les Giblin (Maymunah \& Wartini, 2021) yakni, anak belajar dalam kesehariannya $83 \%$ melalui penglihatan, $11 \%$ melalui pendengaran, $3,5 \%$ melalui penciuman, 1,5 \% melalui sentuhan, dan 1\% melalui rasa. Pemanfaatan video pembelajaran berbasis multimedia interaktif dalam proses pembelajaran akan menggeser pembelajaran yang membosankan menjadi pembelajaran yang menyenangkan (Ariyani \& Ambara, 2021).

Ketertarikan anak akan video pembelajaran juga akan meningkatkan motivasi belajar pada anak. Hasil Temuan penelitian (Fauziah, Wahyuningsih \& Hafidah, 2020) menyatakan bahwa pengembangan bahasa anak dengan menggunakan video pembelajaran untuk meningkatkan keterampilan menyimak dan berbicara dalam menerima dan mengungkapkan bahasanya, terbukti dari anak antusias untuk menyampaikan isi materi dan keterampilan menyimak dari hasil awal yang semula mendapatkan hasil sebesar 62,25 kemudian meningkat menjadi 81,45 dengan tingkat kevalidan media video pembelajaran sebesar $85 \%$. Penelitian lainnya juga dilakukan (Putra, 2015) hasil penelitian terlihat dalam penyajian gambar dan animasi media yang menarik, sehingga memudahkan anak untuk mengingat materi, anak terlihat antusias mengikuti pembelajaran dengan menggunakan multimedia pembelajaran interaktif.

Selanjutnya penelitian yang juga dilakukan oleh (Suseno, Putri et al., 2020) media pembelajaran video interaktif berbasis multimedia dinyatakan valid berdasarkan penilaian pakar baik dari segi media maupun subtansi materi. Dalam penerapannya diperoleh respon positif lebih dari $70 \%$ siswa yang mengikuti proses pembelajaran. Multimedia pembelajaran interaktif sangat efektif untuk pembelajaran anak, karena memiliki berbagai fitur atau menumenu khusus untuk dapat diakses oleh pengguna, untuk dapat memunculkan informasi berupa audio dan visual, animasi, teks, maupun fitur lainnya. Hal ini sejalan dengan penelitian yang dilakukan oleh (Karimah, 2020) terlihat dari hasil yang dinyatakan adanya keefektifan dalam pembelajaran menggunakan multimedia pembelajaran interaktif bolokuncoro mampu meningkatkan kemampuan literasi anak usia 5-6 tahun. Dalam penelitian (Maria, Rusilowati, 2019) terlihat dari hasil penilaian pre-test rata-rata 2,07 - 2,73 untuk post-test dengan penguasaan hasil belajar sebesar $80 \%$, multimedia interaktif mampu membantu pengembangan respon interaktif selama proses pembelajaran.

Perbedaan penelitian ini dengan penelitian yang akan peneliti lakukan adalah penelitian R\&D dengan model ADDIE, pada video pembelajaran disajikan dalam bentuk animasi, audio, dan gambar yang menarik minat anak, dalam pengemasannya memaparkan materi belajar dalam bentuk video pembelajaran dengan tampilan multimedia interaktif, aplikasi yang berisi petunjuk penggunaan, KD/Indikator dan tujuan, video pembelajaran dan profil pengembangan. Pada penggunaan video pembelajaran yang diinovasikan serta didesain menarik berbasis multimedia interaktif, dimana multimedia memiliki alat navigasi atau fitur yang memungkinkan pengguna multimedia dapat menjalin komunikasi dua arah, anak dapat berinteraksi langsung dengan menjalankan atau mengklik icon yang sudah ada di tampilan multimedia untuk meningkatkan keterampilan menyimak anak.

Adapun tujuan penelitian adalah menstimulasi anak untuk meningkatkan kemampuan berbahasanya khususnya dalam keterampilan menyimak. Sehubung dengan hal tersebut, peneliti mencoba untuk meneliti penggunaan video pembelajaran berbasis multimedia interaktif untuk meningkatkan keterampilan menyimak anak usia 5-6 tahun. 


\section{METODOLOGI}

Jenis penelitian yang digunakan adalah penelitian dan pengembangan. Penelitian dan pengembangan adalah metode penelitian yang digunakan untuk menghasilkan produk tertentu dan menguji keefektifan metode tersebut (Maria, Rusilowati, 2019). Metode ini dipilih karena peneliti ingin menghasilkan sebuah produk berupa video pembelajaran berbasis multimedia interaktif untuk meningkatkan keterampilan menyimak anak. Peneliti melakukan penelitian dan pengembangan dengan model ADDIE yang telah dikembangkan oleh (Rusdi, 2018).

Prosedur penelitian dalam penelitian dan pengembangan dengan model ADDIE memiliki lima tahapan yang harus dilakukan antara lain: analyze, design, development, implementation, evaluation. Berikut ini desain tahapan model ADDIE.

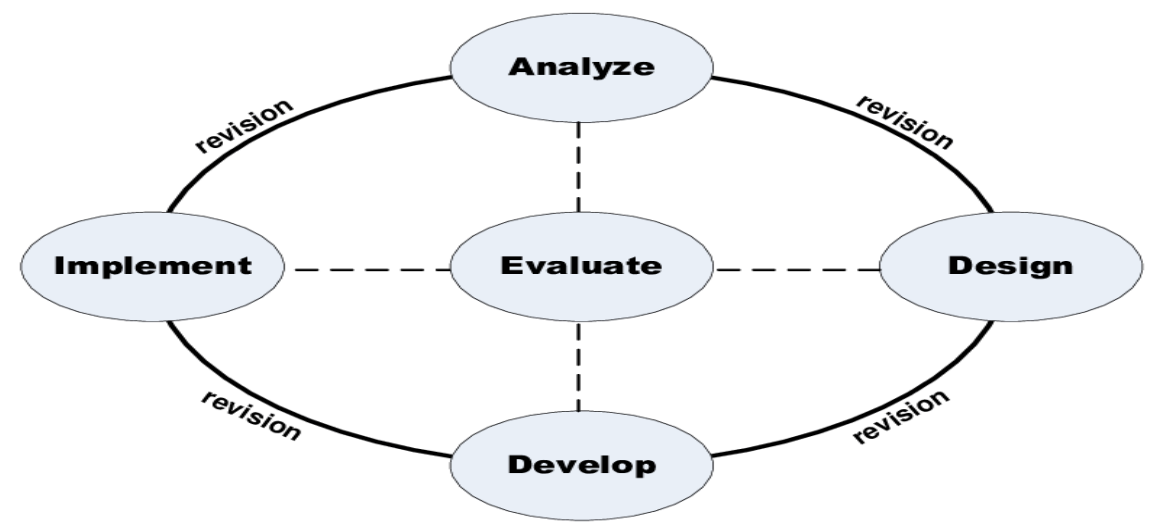

Gambar 1. Tahapan Model ADDIE (Rusdi, 2018)

Adapun subjek dalam penelitian ini adalah ahli materi, ahli media, ahli bahasa dan peserta didik usia 5-6 tahun di TK Miftahul Ilmi Pekanbaru. Teknik pengumpulan data adalah observasi, wawancara, dan angket. Instrumen yang digunakan dalam pengumpulan data yaitu kuesioner/angket. Teknik yang digunakan dalam menganalisis data berupa data kualitatif dan kuantitatif. Teknik analisis data merupakan proses pengolahan data yang diperoleh dari lapangan, peneliti mengunjungi tempat yang akan menjadi subjek penelitian, untuk dilihat apakah layak dijadikan subjek penelitian.

Tahap selanjutnya adalah melakukan proses perizinan terhadap pihak sekolah untuk dijadikan subjek atau tempat penelitian. Penelitian dilaksanakan di sebuah lembaga PAUD yang ada di Kota Pekanbaru. Adapun pertimbangan dipilihnya lembaga ini adalah media pembelajaran berupa video pembelajaran berbasis multimedia interaktif belum ada di Taman Kanak-kanak Miftahul Ilmi.

Data Kualitatif dikumpulkan dari hasil penilaian, masukkan, tanggapan, kritik, serta saran perbaruan melalui angket terbuka yang diperoleh dari hasil angket tanggapan dari review para ahli dan review anak usia 5-6 tahun, sedangkan data kuantitatif yang dikumpulkan melalui angket tertutup yaitu hasil dari penilaian ahli isi atau materi, ahli media dan ahli bahasa dan review anak usia 5-6 tahun.

Instrumen yang digunakan untuk mengumpulkan data pada penelitian ini berupa wawancara dan angket. Metode pengumpulan data dikumpulkan melalui pelaksanaan evaluasi formatif yaitu data hasil review para ahli yaitu ahli materi, data hasil review ahli media, data hasil review ahli bahasa, dan data dari hasil uji coba perorangan berupa hasil review anak. Data-data yang telah terkumpul, kemudian dikelompokkan menurut sifatnya menjadi dua yaitu data kualitatif dan kuantitatif. Data kualitatif dan kuantitatif diperoleh dari hasil review ahli materi melalui angket tanggapan, hasil review ahli media, ahli bahasa, dan hasil review anak melalui uji coba perorangan melalui angket. Pengumpulan data tersebut menggunakan dua metode yaitu wawancara dan kuesioner/angket. 
Teknik pengumpulan data yang digunakan dalam pengembangan media ini adalah berbagai macam instrumen. Instrumen yang akan diimplementasikan sudah divalidasi oleh validator instrumen. Adapun langkah-langkah dalam menyusun lembar validasi, yakni: (1) menentukan aspek yang akan dinilai, (2) menjabarkan aspek perkembangan dalam bentukbentuk indikator-indikator, (3) menyusun butir-butir pernyataan berdasarkan indikator, (4) mengkonsultasikan lembar validasi dengan pembimbing, (5) memberikan lembar validasi pada validator, (6) menganalisis hasil validasi.

Ada beberapa kisi-kisi instrumen kusioner penelitian pengembangan video pembelajaran berbasis multimedia interaktif pada anak usia dini sebagaimana disajikan pada tabel 1 sampai 5.

\section{Tabel 1. Kisi-kisi Instrumen Ahli Materi}

\begin{tabular}{|c|c|c|}
\hline No. & Indikator & Butir Pernyataan \\
\hline 1. & $\begin{array}{l}\text { Isi dan Tujuan } \\
\text { Pembelajaran }\end{array}$ & $\begin{array}{l}\text { 1. Kesesuaian isi materi dari kompetensi Inti (KI) dan Kompetensi Dasar (KD). } \\
\text { 2. Kesesuaian Indikator dengan kompetensi Dasar (KD) dalam kurikulum. } \\
\text { 3. Kesesuaian tujuan pembelajaran dengan indikator. } \\
\text { 4. Kesesuaian narasi (audio). }\end{array}$ \\
\hline 2. & $\begin{array}{l}\text { Penyajian } \\
\text { Materi }\end{array}$ & $\begin{array}{l}\text { 1. Penyajian materi mudah dipahami. } \\
\text { 2. Materi disajikan secara sistematis dan berurutan. } \\
\text { 3. Kesesuaian isi materi dengan keterampilan menyimak anak usia 5-6 tahun. }\end{array}$ \\
\hline 3. & $\begin{array}{c}\text { Kualitas } \\
\text { Instruksional }\end{array}$ & $\begin{array}{l}\text { 1. Meningkatkan motivasi belajar anak. } \\
\text { 2. Meningkatkan minat belajar anak. } \\
\text { 3. Membantu anak maupun guru dalam proses pembelajaran. }\end{array}$ \\
\hline
\end{tabular}

Tabel 2. Kisi-kisi Instrumen Ahli Media

\begin{tabular}{|c|c|c|}
\hline No. & Indikator & Butir Pernyataan \\
\hline 1. & Tampilan & $\begin{array}{l}\text { 1. Penempatan judul, maupun sub-sub judul dari media jelas. } \\
\text { 2. Ketepatan jenis dan ukuran font. } \\
\text { 3. Kesesuaian dari teks dan warnanya. } \\
\text { 4. Kejelasan gambar. } \\
\text { 5. Kesesuaian suara musik instrumen pada tampilan background. } \\
\text { 6. Warna background dengan teks, gambar, dan tampilan tombol navigasi } \\
\text { menarik. } \\
\text { 7. Animasi teks mendukung kualitas tampilan setiap frame menarik. }\end{array}$ \\
\hline 2. & $\begin{array}{l}\text { Kemudahan } \\
\text { penggunaan }\end{array}$ & $\begin{array}{l}\text { 1. Tombol navigasi berfungsi. } \\
\text { 2. Sistematis dalam penyajian. } \\
\text { 3. Petunjuk penggunaan media jelas dan mudah dipahami. }\end{array}$ \\
\hline 3. & Kemanfaatan & $\begin{array}{l}\text { 1. Menarik perhatian dan minat anak. } \\
\text { 2. Membantu anak dalam proses pembelajaran. } \\
\text { 3. Kemudahan dalam menjalankan aplikasi media belajar. } \\
\text { 4. Dapat meningkatkan keterampilan menyimak anak. }\end{array}$ \\
\hline
\end{tabular}

Tabel 3. Kisi-kisi Instrumen Ahli Bahasa

\begin{tabular}{ccl}
\hline No. & Indikator & \multicolumn{1}{c}{ Butir Pernyataan } \\
\hline 1. & Kebahasaan & 1. Bahasa dalam media mudah dipahami untuk anak usia 5-6 tahun. \\
& & 2. Merangsang anak berpikir secara kontekstual. \\
& 3. Kejelasan bahasa dari petunjuk penggunaan sound effect tombol button. \\
& 4. Kesesuaian dubbing dalam pemaparan materi dari video pembelajaran. \\
& 5. Isi video pembelajaran dapat meningkatkan keterampilan menyimak anak. \\
2. Keterbacaan & 1. Kesesuaian penggunaan bahasa Indonesia. \\
& 2. Tata letak teks sudah sesuai. \\
& 3. Ketepatan jenis dan ukuran font. \\
4. Ketepatan warna teks sudah sesuai.
\end{tabular}


Tabel 4. Kisi-kisi Instrumen Uji Perorangan, Kelompok Kecil dan Uji Lapangan

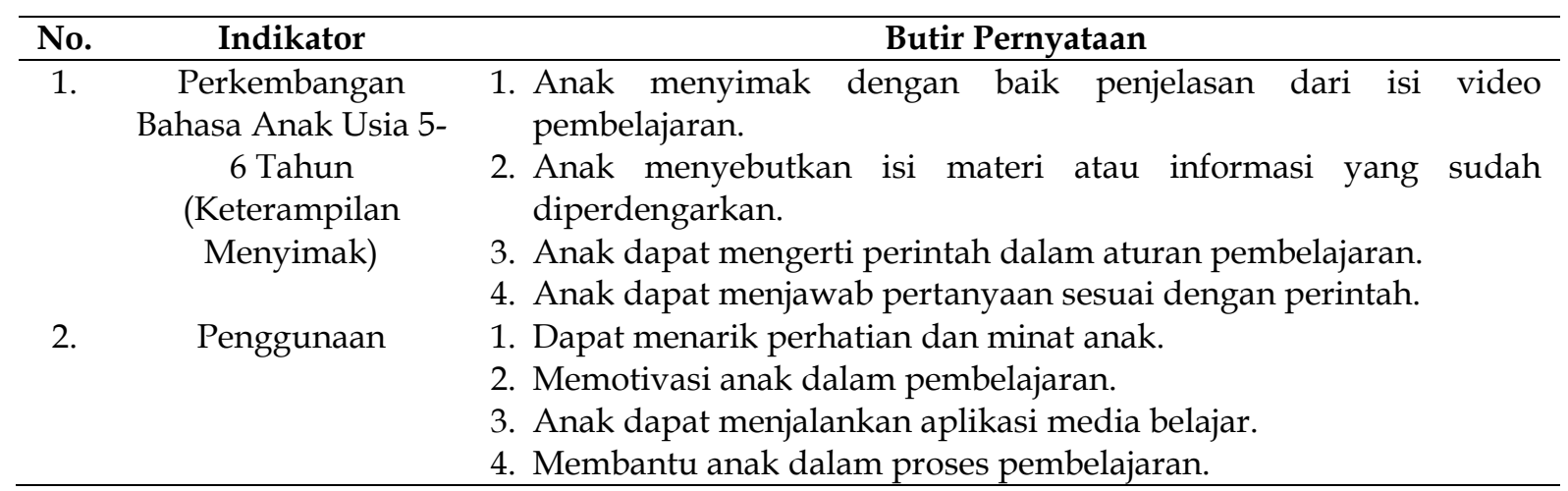

Tabel 5. Instrumen Wawancara

\begin{tabular}{cl}
\hline No. & \multicolumn{1}{c}{ Daftar Pertanyaan } \\
\hline 1. & $\begin{array}{l}\text { Berdasarkan pengamatan yang sudah ibu lakukan, sebagian besar anak didik berada } \\
\text { dalam tahap apa perkembangan bahasa, khususnya pada keterampilan menyimaknya? }\end{array}$ \\
2. & $\begin{array}{l}\text { Apakah ada kendala yang ibu alami dalam memberikan stimulasi pada keterampilan } \\
\text { menyimak? }\end{array}$ \\
3. & $\begin{array}{l}\text { Metode apa saja yang digunakan ibu dalam pembelajaran khususnya pada keterampilan } \\
\text { menyimak? }\end{array}$ \\
4. Apakah ibu sudah menggunakan beragam media agar suasana pembelajaran menjadi \\
lebih bervariatif? \\
Apa media berbasis teknologi sudah pernah ibu gunakan untuk menstimulasi \\
keterampilan menyimaknya anak?
\end{tabular}

Dalam menganalisis data dilakukan langkah-langkah sebagai berikut: (1) melakukan proses pengumpulan data terhadap responden yang telah ditentukan sebelumnya yakni validator/para ahli materi, ahli media, ahli bahasa, dan guru sebagai penilai anak, (2) untuk menganalisis data tersebut, skor jawaban yang diberikan validator ahli materi, ahli media, ahli bahasa, dan guru berdasarkan skala likert. Skala likert digunakan untuk mengukur sikap, pendapat dan persepsi seseorang ataupun kelompok tentang fenomena sosial (Sugiyono, 2013), (3) kemudian meminta validator ahli untuk memberikan saran atas penilaian yang diberikan terhadap pengembangan video pembelajaran berbasis multimedia interaktif berdasarkan item-item yang terdapat pada uji validitas. Jika masih banyak terdapat kesalahan dalam pengembangan, maka perlu dilakukannya revisi agar benar-benar valid atas video yang dikembangkan, (4) menentukan jumlah skor yang diperoleh dari masing-masing indikator, (5) untuk mengubah skor menjadi nilai. Sunarti \& Rachmawati, (2014) mengatakan rumus yang digunakan sebagai berikut:

$$
\text { Nilai Validitas }=\frac{\text { Jumlah skor yang diperoleh }}{\text { Jumlah skor maksimum }} \times 100 \%
$$

(6) selanjutnya, memberikan penilaian validasi dengan kriteria persentase responden validitas. Untuk dapat memberikan makna dan pengambilan keputusan digunakan ketetapan konversi tingkat pencapaian dengan Likert sebagaimana pada tabel 5.

Tabel 5. Konversi Tingkat Pencapaian dengan Likert

\begin{tabular}{|c|c|c|c|}
\hline Tingkat Pencapaian \% & Nilai Angka & Nilai Huruf & Kategori \\
\hline $90-100$ & 4 & A & Sangat Baik \\
\hline $80-89$ & 3 & B & Baik \\
\hline $65-78$ & 2 & C & Cukup \\
\hline $40-64$ & 1 & D & Kurang \\
\hline $00-39$ & 0 & E & Sangat Kurang \\
\hline
\end{tabular}

Sumber: Riduwan (2013) 


\section{HASIL DAN PEMBAHASAN}

Berdasarkan hasil penelitian pada tahap ini akan dipaparkan rancangan dan validitas dari pengembangan video pembelajaran berbasis multimedia interaktif untuk keterampilan menyimak anak usia 5-6 tahun. Pada tahap pertama adalah Analysis (Analisis) merupakan tahap awal dari peneliti melakukan observasi di TK Miftahul Ilmi Pekanbaru. Berdasarkan observasi yang dilakukan di kelompok B, dalam proses pembelajarannya masih ditemukan keterampilan menyimak anak dalam aspek bahasa masih kurang optimal. Terlihat anak kurang memahami ujaran yang didengarkan, ditambah kurangnya bantuan media pembelajaran yang mendukung anak dalam proses pembelajaran sehingga anak sulit dalam berkonsentrasi, dan kurang termotivasi sehingga tidak dapat memperhatikan pembelajaran dengan baik, anak belum mampu menginterpretasikan suatu cerita atau informasi yang didengarnya berdasarkan kemampuan bahasa dan daya imajinasinya. Selain itu guru cenderung menggunakan model konvensional yaitu pembelajaran yang menekankan kepada proses penyampaian materi secara verbal, guru lebih berorientasi pada materi yang ada pada buku teks sebagai sumber belajar dalam melaksanakan proses pembelajaran sehingga anak mengalami kesulitan dalam menerima pembelajaran karena kegiatan pembelajaran yang kurang menarik perhatian anak.

Tahap kedua adalah Design (Desain). Melihat permasalahan dan fasilitas yang belum dimanfaatkan secara efektif dan efisien yang terdapat di sekolah, peneliti mengumpulkan informasi sebagai penunjang pengembangan video pembelajaran berbasis multimedia interaktif. Berdasarkan pada analisis kebutuhan maka diperlukan media baru yang memiliki kemudahan dalam pengoperasiannya. Media tersebut disesuaikan dengan perkembangan teknologi sekarang ini. Pada tahapan ini peneliti merancang desain video pembelajaran berbasis multimedia interaktif berupa storyboard dan flowchar.

Kegiatan dimulai dari penyusunan tema/sub tema, menyusun naskah cerita membuat video pembelajaran, guru menginformasikan kepada anak tentang makanan 4 sehat 5 sempuran dengan asal mula makanan dan minuman, kemudian dilanjutkan dengan guru memberikan pertanyaan dalm bentuk games dimana anak dapat menjawab pertanyaan yang diberikan ibu guru. Video pembelajaran dikemas dengan menggunakan tampilan animasi, audio, dan gambar yang dapat menarik perhatian anak dan dapat meningkatkan keterampilan menyimak anak. Untuk pemilihan software aplikasi dalam membuat video edukasi peneliti menggunakan, zepeto, photoscape, inshot, kinemaster, dan android sebagai alat perekam suara, kemudian produk yang dikembangan dengan tampilan multimedian interaktif dirancang dengan menggunakan aplikasi smart apps creator.

Durasi pada video pembelajaran terdiri dari 7 menit 18 detik untuk mengenalkan makanan 4 sehat 5 sempurna, dan 8 menit 10 detik untuk mengenalkan asal mula makanan dan minuman. Desain yang digunakan menampilkan latar dan warna background dengan teks, gambar, dan tampilan tombol navigasi menarik, diiringi music instrument pada tampilan background multimedia. Jenis produk yang dihasilkan dapat dibuka dengan CD (compact Disk) ataupun Flashdisk, untuk video pembelajaran dapat diputar dengan media player atau windows media player. Adapun flowchart dari media video pembalajaran yang dikemas menggunakan multimedia interaktif sebagaimana disajikan pada gambar 2.

Tahap ketiga yaitu Development (Pengembangan). Tahap ini dilakukan apabila tahap desain sudah dilakukan hingga selesai. Pada tahap ini dilakukannya pembuatan video pembelajaran berbasis multimedia interaktif yang telah direncanakan. Desain kemudian di konsultasikan kepada para ahli kemudian para ahli memberikan masukan atau saran bahwa media video pembelajaran berasis multimedia interaktif harus dibuat semenarik mungkin. Adapaun tahapan pengembangan meliputi penentuan materi, konsep video pembelajaran, menentukan gambar yang sesuai dengan topik yang akan dibahas, video editing dengan menggunakan berbagai aplikasi pendukung seperti photoscape, inshot, Kinemaster serta aplikasi smart apps creator. Peneliti memilih video pembelajaran berbasis multimedia interaktif untuk memberikan kemudahan bagi guru maupun peserta didik dalam menginformasikan materi 
belajar, disajikan secara unik dengan menggunakan tampilan animasi, gambar, sound effect, serta musik yang sesuai agar menarik perhatian anak.

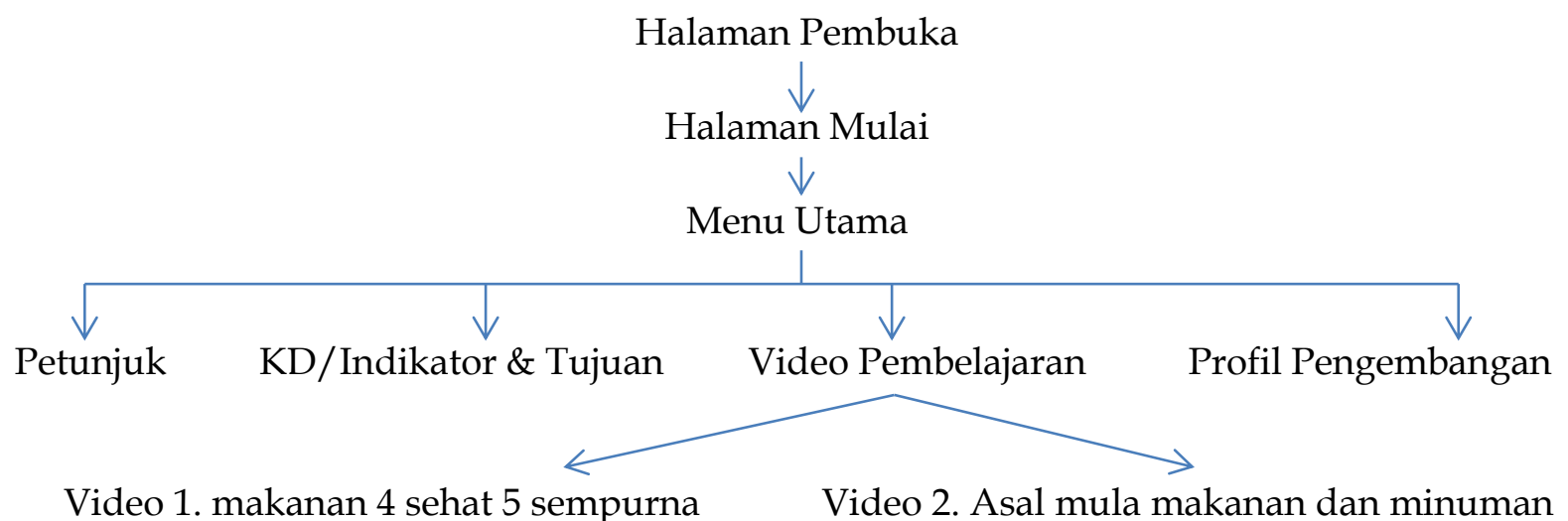

Gambar 2. Flowchart Media Video Pembelajaran
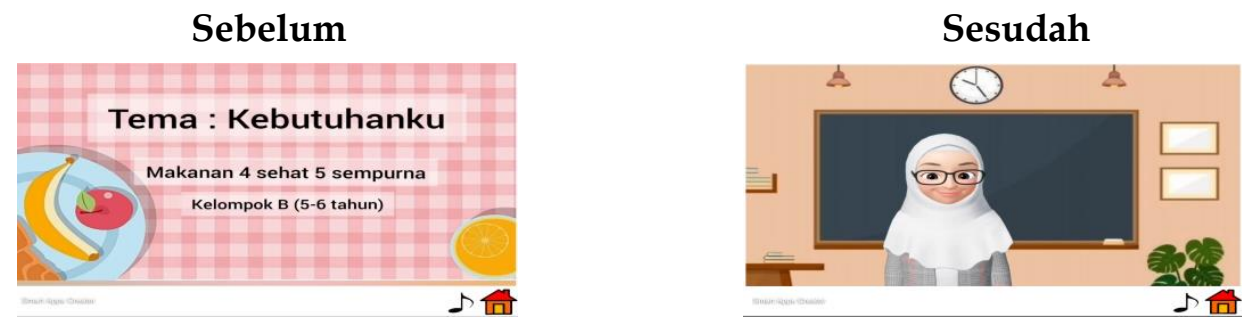

Gambar 3. Tampilan Revisi Cover Video Pembelajaran oleh Ahli Materi

Keterangan :

1. Sebelumnya di awal video tidak mencantumkan cover, namun langsung menampilkan animasi guru.

2. Setelah dilakukan perbaikan atau revisi, pada awal video di beri tulisan judul atau materi yang akan di sampaikan serta ditujukan untuk kelompok B usia 5-6 tahun.
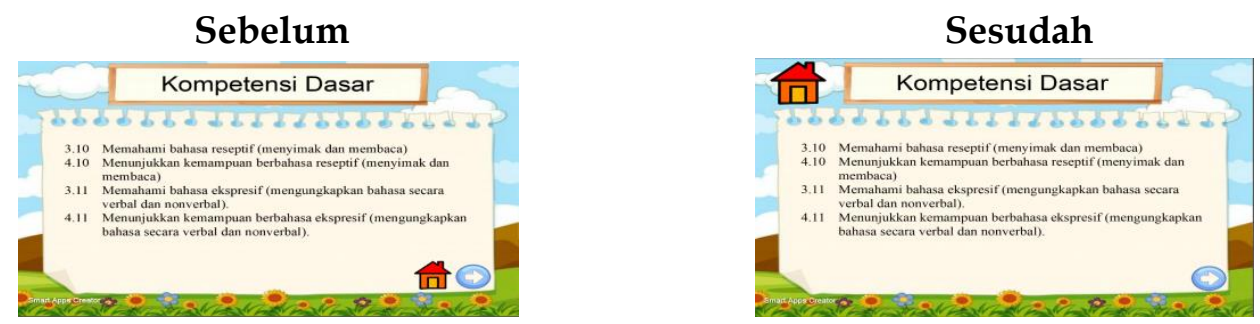

Gambar 3. Tampilan Revisi Tata Letak Tombol Home oleh Ahli Media

Keterangan :

1. Sebelumnya di tampilan multimedia ini terlihat tombol home berada di atas dekat judul.

2. Setelah dilakukan perbaikan atau revisi, tata letak tombol home berada di samping tombol next.
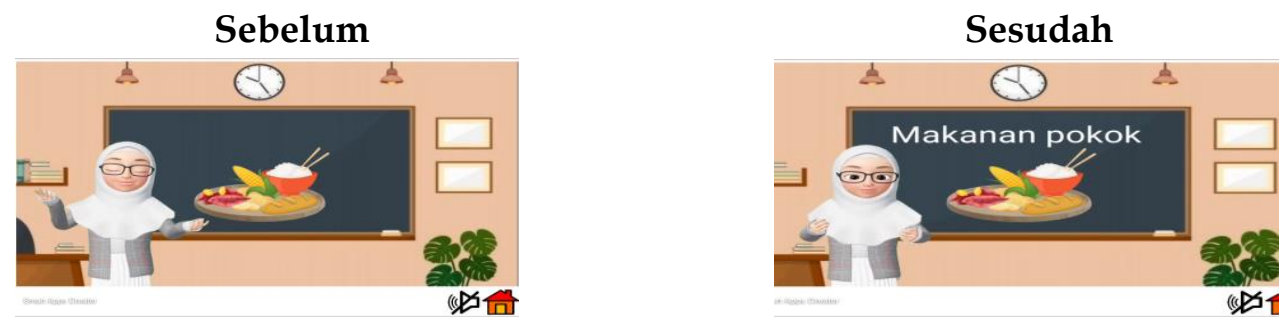

Gambar 4. Tampilan Revisi Video Pembelajaran oleh Ahli Bahasa 
1. Sebelumnya di tampilan video pembelajaran hanya mencantumkan gambar makanan pokok disertai penjelasan dari guru.

2. Setelah dilakukan perbaikan atau revisi, peneliti menambahkan tulisan "makanan pokok" agar dapat memperjelas informasi yang disampaikan dari guru kepada anak. Adapun Uji validitas dari ahli media diperoleh hasil sebesar 93\% dengan kategori sangat baik. Uji validitas ahli bahasa diperoleh hasil sebesar $85 \%$ dengan kategori baik.

Tahap keempat adalah Implementation (Implementasi). Tahap ini merupakan tahap penerapan media video pembelajaran berbasis multimedia interaktif yang sudah dinyatakan layak oleh para ahli. Implementasi media video pembelajaran dilaksanakan di Taman Kanakkanak Miftahul Ilmi Pekanbaru, anak usia 5-6 tahun kelompok B pada uji coba perorangan. Pengembangan media belajar menggunakan video pembelajaran berbasis multimedia interaktif. Kelayakannya diukur dengan kriteria interpretasi skor likert. Adapun hasil validitas dari media pembelajaran berbasis multimedia interaktif ini yaitu sebagai berikut. Uji Validitas ahli materi diperoleh hasil sebesar $85 \%$ dengan kategori baik. Uji validitas ahli media diperoleh hasil sebesar 93\% dengan kategori sangat baik. Uji validitas ahli bahasa diperoleh hasil sebesar $85 \%$ dengan kategori baik. Uji coba perorangan yang dilakukan anak kelompok B di TK Miftahul Ilmi Pekanbaru mendapat hasil rata-rata 91\% dengan kategori sangat baik.

Tahap kelima adalah Evaluation (Evaluasi). Tahap terakhir yang dilakukan adalah evaluasi. Tujuannya adalah untuk membandingkan hasil dari uji coba produk yang dilakukan oleh para ahli materi, ahli media, ahli bahasa. Selain itu dilakukan analisis data yang diperoleh dari anak untuk mengetahui pendapat respon mengenai media yang telah dikembangkan. Persentase hasil validitas video disajikan pada tabel 6.

\section{Tabel 6. Persentase Hasil Validitas Video Pembelajaran Berbasis Multimedia Interaktif untuk} Meningkatkan Keterampilan Menyimak Anak

\begin{tabular}{cccc}
\hline No. & Nama Validator & Persentase Skor & Kategori \\
\hline 1. & Uji Ahli Materi & $85 \%$ & Baik \\
2. & Uji Ahli Media & $93 \%$ & Sangat Baik \\
3. & Uji Ahli Bahasa & $85 \%$ & Baik \\
4. & Uji Coba Perorangan & $91 \%$ & Sangat Baik \\
\hline
\end{tabular}

Berdasarkan penilaian dari para pakar, diketahui bahwa video pembelajaran berbasis multimedia interaktif yang telah dikembangkan sudah sesuai dan layak untuk digunakan dalam kegiatan pembelajaran khususnya keterampilan menyimak anak usia dini. Hal tersebut dilihat dari beberapa aspek. Penyajian materi pada video pembelajaran berbasis multimedia interaktif yang dikembangkan, disusun sesuai dengan kompetensi dasar dan indikator yang sesuai dengan tujuan pembelajaran yang hendak dicapai, penyajian materi mudah dipahami, meningkatkan motivasi dan minat belajar anak, membantu anak maupun guru dalam proses pembelajaran.

Kedua, dari aspek media video pembelajaran berbasis multimedia interaktif berada pada kategori baik, ditinjau dari sisi desain media yang dikembangkan dan kesesuaian materi dengan media yang dikembangkan yang didalamnya terdapat teks, animasi, gambar, audio yang dirancang menarik dan sesuai dengan perkembangan anak, sehingga diharapkan mampu menjadikan anak semangat belajar. Multimedia interaktif yang merupakan perpaduan teks, gambar, animasi, suara, dan video menuntut keterlibatan banyak indera dalam proses belajar (Havizul, 2019). Keterlibatan berbagai indera dalam proses belajar dapat memudahkan siswa dalam hal memperoleh ilmu. Semakin banyak indera yang terlibat maka semakin banyak ilmu yang diperoleh (Istiqlal, 2017). Tidak hanya dari segi materi dan media melainkan kebahasaan dan keterbacaan pada media video merangsang anak berpikir secara kontekstual, bahasa dalam media mudah dipahami untuk anak usia 5-6 tahun, ketepatan jenis ukuran font, dan ketepatan warna teks sudah sesuai. Media pembelajaran merupakan alat 
yang dapat memperjelas penyajian pesan dan informasi sehingga dapat memperlancar dan meningkatkan proses dan hasil belajar (Surachman, 2020). Untuk mewujudkan hal tersebut tentunya memerlukan media pembelajaran yang kreatif sebagai sarana untuk dapat menyampaikan materi dalam pembelajaran dengan lebih interaktif (Kurniawan, 2018).

Berdasarkan validasi dari ahli materi, ahli media, dan ahli bahasa maka, dapat diketahui video pembelajaran berbasis multimedia interaktif yang telah dikembangkan sudah layak sehingga dapat dipergunakan dalam kegiatan pembelajaran anak. Ketika di uji cobakan peneliti mengamati bahwa anak-anak terlihat antusias dan memiliki motivasi lebih dari pada hari biasanya. Video adalah salah satu metode terbaik untuk menarik anak untuk menikmati dan memahami materi yang disampaikan (Mendoza, G. L. L., Caranto, L. C., \& David, 2015). Menarik perhatian anak seperti, ekspresi anak terlihat ketika proses pembelajaran berlangsung menunjukkan bahwa mereka ingin tahu lebih jauh tentang apa yang sedang mereka lihat, memotivasi anak dalam pembelajaran khususnya untuk meningkatkan keterampilan menyimak. Selanjutnya dari hasil penelitian (Fahrurozi, Slamet, 2017) mengemukakan responden (peserta didik) sangat menyukai video, $75 \%$ melaporkan bahwa video sangat menyenangkan dan menarik perhatian, 84,6\% menunjukkan bahwa, video memebuhi kebutuhan anak dalam proses pembelajaran, $100 \%$ mengatakan video sangat mudah untuk dipahami, 92,4\% setuju bahwa durasi dalam video sudah sesuai, 90,8 \% percaya bahwa video dapat memberi peserta didik pemahaman yang lebih baik lagi dari pada buku teks dan lembar panduan.

Temuan diperkuat dengan penelitian sebelumnya yang menyatakan multimedia pembelajaran interaktif efektif diterapkan pada siswa, karena menarik minat belajar siswa (Yuniarni., Sari., \& Atiq, 2019). Video pembelajaran multimedia interaktif membantu siswa dalam pembelajaran karena disajikan dengan menggabungkan teks, gambar, suara, video dan animasi (Pratomo, 2019). Multimedia interaktif merupakan suatu tampilan multimedia yang dirancang agar tampilannya memenuhi fungsinya menginformasikan pesan serta memiliki interaktifitas dengan penggunanya (Munir, 2012). Hal senada juga dikemukakan (Ramadhani, M., Gafari, M. O. F., \& Marice, 2019) dalam penelitiannya mengatakan, multimedia memberikan ruang kepada pengguna untuk berinteraksi dengan materi. Interaksi ini bervariasi karena pengguna dapat memilih materi yang akan dipelajari, memindahkan halaman yang diinginkan, merespons dengan memberikan umpan balik kepada penggunanya. Selanjutnya Roemintoyo (2021) juga mengatakan, multimedia interaktif merupakan salah satu media pembelajaran jenis dengan kemampuan menampilkan materi dalam bentuk audiovisual dan memungkinkan interaksi terjadi antara siswa dan media. Penggunaan multimedia dalam proses pembelajaran dapat meningkatkan motivasi belajar, dan dapat mendukung efektivitas dan efisiensi pembelajaran, serta dapat meningkatkan pencapaian tujuan pembelajaran yang telah ditentukan (Wiana, 2017). Aplikasi multimedia interaktif menyediakan materi pembelajaran dengan tampilan yang lebih manarik dan informatif, diharapkan dapat mempermudah dan meningkatkan minat peserta didik untuk belajar.

Penelitian ini, tidak sepenuhnya bisa berjalan dengan baik. Adapun keterbatasan dalam penelitian pengembangan aplikasi video pembelajaran berbasis multimedia interaktif ini antara lain, produk aplikasi video pembelajaran berbasis multimedia interaktif yang dihasilkan masih termasuk pengembangan tingkat pemula, hanya mencakup satu materi pokok saja. Uji coba pengembangan hanya dibatasi pada anak kelompok B di TK MIftahul Ilmi Pekanbaru. Keterbatasan pengembangan ini dapat dilanjutkan dengan memperluas subyek penelitian yang tidak hanya dibatasi satu kelompok saja melainkan seluruh kelompok usia. Keterbatasan waktu dan media membuat implementasi media hanya bisa diuji dengan jumlah anak sebanyak 3 orang. Untuk memastikan pengembangan aplikasi berjalan lebih baik, sebaiknya dapat diuji coba kepada banyak anak untuk memastikan keefektifitasan media. Video pembelajaran berbasis multimedia interaktif ini hanya terbatas pada satu pokok materi yaitu tentang mengenalkan makanan 4 sehat 5 sempurna dengan tema kebutuhanku. 


\section{SIMPULAN}

Pembelajaran akan lebih menyenangkan dan bervariatif untuk anak apabila guru mampu mengintegrasikan situasi yang serba teknologi ini ke kelas. Implikasi dari penelitian pengembangan video berbasis multimedia interaktif pada aspek bahasa khususnya keterampilan menyimak dapat dijadikan salah satu solusi pada permasalahan yang ada, yaitu untuk sekolah media belajar ini dapat digunakan sebagai salah satu media yang dapat digunakan anak pada pembelajaran untuk meningkatkan keterampilan anak khususnya keterampilan menyimak. Selain itu media ini dapat membantu pembelajaran menjadi lebih variatif sehingga pembelajaran lebih menarik dan dapat memberikan pengalaman belajar bagi anak.

\section{UCAPAN TERIMA KASIH}

Penulis mengucapkan terimakasih kepada semua pihak yang telah membantu kegitan penelitian ini. Secara khusus, penulis berterimakasih kepada kepala sekolah, guru dan peserta didik di TK Miftahul Ilmi Pekanbaru yang telah menjadi partisipan dan turut membantu memberikan fasilitas dalam proses penelitian ini. Selain itu, penulis juga berterimakasih kepada keluarga dan semua pihak yang telah membantu dalam menulis artikel ini.

\section{DAFTAR PUSTAKA}

Ariawan, V, A, N., Agustin, E, D., \& R. (2019). Bermain Sebagai Sarana Mengembangkan Keterampilan Menyimak Anak Usia Dini. Jurnal Pendidikan Raudhatul Athfal, 2(1), 26-36. https:// doi.org/10.15575/japra.v2i1.5310

Ariyani, N, W \& Ambara, D, P. (2021). Video Pembelajaran Berbasis Multimedia Interaktif pada Aspek Kognitif Anak Usia Dini. Jurnal Pendidikan Anak Usia Dini Undiksha, 9(2), 252-260. https://doi.org/10.23887/paud.v9i2.36043

Asmoro, S, W. (2019). Teknik Pengolahan Audio \& Video. Andi.

Dewi, K. Y. O., Suwatra, W., \& Magta, M. (2016). Penerapan Metode Bercerita Berbantuan Media Boneka Jari Untuk Meningkatkan Kemampuan Menyimak Anak di TK Waringin Sari. Journal Pendidikan Anak Usia Dini, 4(3). http:/ / dx.doi.org/10.23887/paud.v4i3.8896

Fahrurozi, Slamet, K. (2017). The Development of Video Learning to Deliver a Basic Algorithm Learning. Indonesian Journal of Informatics Education, 1(2), 49-56. https://doi.org/10.20961/ijie.v1i2.12446

Fauziah, Z., Wahyuningsih, S., \& Hafidah, R. (2020). Metode Sosiodrama Untuk Meningkatkan Keterampilan Berbicara Pada Anak Usia 5-6 Tahun. Kumara Cendikia, 8(2), 222-241. https://doi.org/10.20961/kc.v8i2.39266

Havizul. (2019). Pengembangan Multimedia Interaktif Untuk Pembelajaran IPS Di Sekolah Dasar Menggunakan Model DDD-E. Jurnal Pendidikan Sosial, 6(2), 283-297. https://doi.org/10.31571/sosial.v6i2.1202

Istiqlal, M. (2017). Pengembangan Multimedia Interaktif Dalam Pembelajaran Matematika. JIPMat, 2(1), 43-54. https:// doi.org/10.26877/jipmat.v2i1.1480

Karimah, L. (2020). Pengembangan Multimedia Pembelajaran Interaktif "Bolokuncoro" Dalam Kemampuan Literasi Anak Usia Dini Di Kota Solo. Universitas Negeri Semarang. Thesis.

Kemendikbud. (2014). Peraturan Menteri Pendidikan dan Kebudayaan Republik Indonesia Nomor 146 Tentang Kurikulum 2013 PAUD. Kementrian Pendidikan dan Kebudayaan.

Kirana, M. (2016). The Use of Audio Visual to Improve Listening. English Education Journal, $7(2), 233-245$. 
Kurniawan, M. P. (2018). Perancangan Media Pembelajaran untuk Anak Usia Dini Mengenal Nama-Nama Benda. Jurnal Amikom, 6(1), 11-25. https://ojs.amikom.ac.id/index.php/semnasteknomedia/article/view/2010.

Limbong, Tonni \& Simarmata, J. (2020). Media dan Multimedia Pembelajaran: Teori \& Praktik. Yayasan Kita Menulis.

Maria, Rusilowati, \& H. (2019). Interactive Multimedia Development in The Learning Process of Indonesian Culture Introduction Theme for 5-6 Year Old Children. Journal of Primary Education, 8(3), 34-353. https://doi.org/https://doi.org/10.15294 /jpe.v8i3.27929

Maymunah, S \& Wartini, S. (2021). Pemanfaatan Media Video Dalam Pembelajaran Anak Usia Dini Di Masa Pandemi Covid - 19. Jurnal Pendidikan Tambusai, 5(2), 4120-4127. https://jptam.org/index.php/jptam/article/view/1520

Mendoza, G. L. L., Caranto, L. C., \& David, J. J. T. (2015). Effectiveness of Video Presentation to Students' Learning. International Journal of Nursing Science, 5(2), 81-86. https:/ / doi.org/doi:10.5923/j.nursing.20150502.07

Mianawati, R, Hayati, T, \& Kurnia, A. (2019). Keterampilan Menyimak pada Anak Usia Dini Melalui Metode Bercerita. Jurnal Pendidikan Raudhatul Athfal, 2(1), 2-14. https:// doi.org/10.15575/japra.v2i1.5308

Munir. (2012). Multimedia Konsep \& Aplikasi dalam Pendidikam. Alfabeta.

Nurhafizah. (2018). Pelatihan Pembuatan Media Pembelajaran Anak Usia Dini Menggunakan Bahan Sisa. Jurnal Pendidikan, 2(2), 1-10. https:// doi.org/10.35568/earlychildhood.v2i2b.288

Oduolowu, E \& Oluwakemi, A, E. (2014). Effect of Storytelling on Listening Skills of Primary One Pupil in Ibadan North Local Government Area of Oyo State, Nigeria. International Journal of Humanities and Social Science, 4(9). www.ijhssnet.com

Pradilasari, dkk. (2019). Pengembangan Media Pembelajaran Berbasis Audio Visual pada Materi Koloid Untuk Meningkatkan Motivasi dan Hasil Belajar Siswa SMA. Jurnal Pendidikan Sains Indonesia (Indonesian Journal of Science Education), 7(1), 9-15. https://doi.org/10.24815/jpsi.v7i1.13293

Pratomo, A. (2019). Media Interaktif Berbasis Android. Deepublish.

Puspitasari, W. (2019). Pintar Bercerita. CV. Kekata Group.

Putra, L, D. \& I. (2015). Pengembangan Multimedia Pembelajaran Interaktif Mengenal Angka dan Huruf untuk Anak Usia Dini. Jurnal Inovasi Teknologi Pendidikan, 2(2), 169-178. https://doi.org/10.21831/tp.v2i2.7607

Putu, D. W., Sudarma, I., \& Yuda, W, I. (2019). Pengembangan Media Video Pembelajaran Berorientasi Pendidikan Karakter. Journal of Education Technology, 3(3), 140-146. https:// doi.org/10.23887/jet.v3i3.21735

Ramadhani, M., Gafari, M. O. F., \& Marice, M. (2019). Development of Interactive Learning Media on Material Writing Short Story Texts Based on Experience. Budapest International Research and Critics in Linguistics and Education (BirLE) Journal, 2(1), 91-102.

https:// doi.org/10.33258/birle.v2i1.189

Retnaningrum, W. (2016). Peningkatan Perkembangan Kognitif Anak Usia Dini Melalui Media Bermain Memancing. Jurnal Pendidikan Dan Pemberdayaan Masyarakat, 3(2), 207218. https://doi.org/10.21831/jppm.v3i2.11284

Riduwan. (2013). Metode dan Teknik Menyusun Proposal Penelitian. Alfabeta.

Rismark, Marit \& Selvberg, A. M. (2019). Video as a Learner Scaffolding Tool. International Journal of Learning, Teaching and Educational Research, 18(1), 62-75. https:// doi.org/10.26803/ijlter.18.1.5

Roemintoyo, dkk. (2021). The Effect of Interactive Multimedia to Improve the Cognitive Learning Outcome in Senior High School's Student. International Journal of Education and Knowledge Management, 4(1), 1-9. https://doi.org/10.37227/IJEKM-2021-01-34 
Rusdi, M. (2018). Penelitian Desain dan Pengembangan Kependidikan (Konsep, Prosedur dan Sintesis Pengetahuan Baru). PT. Raja Grafindo Persada.

Sugiyono. (2013). Statistika untuk Penelitian. Alfabeta.

Sujiono, Y. N. (2013). Konsep Dasar Pendidikan Anak Usia Dini. Jakarta: PT Indeks.

Sukiman. (2012). Pengembangan Media Pembelajaran. Pustaka Insan Madani.

Sulaiman, U., Ardianti, N., \& S. (2019). Tingkat Pencapaian Aspek Perkembangan Anak Usia 5-6 Tahun Berdasarkan Standar Nasional Pendidikan Anak Usia Dini. Nanaeke Indonesian Journal of Early Childhood Education, 2(1), 52-65. https://doi.org/10.24252/nananeke.v2i1.9385

Sunarti \& Rachmawati, S. (2014). Penilaian dalam kurikulum 2013 Membantu Guru dan Calon Guru Mengetahui Langkah-langkah Penilaian pembelajaran. CV. Andi Offset.

Surachman, D. (2020). Efektifitasnya Untuk Meningkatkan Hasil Belajar Bahasa Indonesia Siswa Sekolah Dasar. Jurnal Gema Wiralodra, 11(2), 180-189. https://doi.org/10.31943/gemawiralodra.v11i2.99

Suseno, Putri, U., Ismail, Y., \& Sumarno, I. (2020). Pengembangan Media Pembelajaran Matematika Video Interaktif berbasis Multimedia. Journal of Mathematics Education, 1(2), 59-74. https:// doi.org/10.34312/jmathedu.v1i2.7272

Tarigan. (2015). Menyimak Sebagai Suatu Keterampilan Berbahasa. Angkasa.

Wiana, W. (2017). Interactive Multimedia-Based Animation: A Study of Effectiveness on Fashion Design Technology Learning. Journal of Physics: Conference Series, 1-8. https://doi.org/10.1088/1742-6596/953/1/012024

Widyastuti, A. (2018). Analisis Upaya Guru dalam Mengembangkan Bahasa pada Anak Usia 5-6 Tahun di Taman Kanak-kanak Assaadah Limo Depok. Jurnal Care, 6(1), 10-17. https://doi.org/10.29406/jepaud.v6i1.1363

Yuniarni, D., Sari, R. P., \& Atiq, A. (2019). Pengembangan Multimedia Interaktif Video Senam Animasi Berbasis Budaya Khas Kalimantan Barat. Jurnal Obsesi : Jurnal Pendidikan Anak Usia Dini, 4(1), 280-294. https://doi.org/10.31004/obsesi.v4i1.331 